\title{
THE EFFECT OF THE CONDITIONS OF SHOT PEENING THE INCONEL 718 NICKEL ALLOY ON THE GEOMETRICAL STRUCTURE OF THE SURFACE
}

\author{
Kazimierz Zaleski' ${ }^{1}$ Agnieszka Skoczylas' ${ }^{1}$, Małgorzata Brzozowska' \\ 1 Faculty of Mechanical Engineering, Lublin University of Technology, Nadbystrzycka 36, 20-618 Lublin, Poland, \\ e-mail: a.skoczylas@pollub.pl,k.zaleski@pollub.pl
}

Received: 2017.04.05

Accepted: 2017.05.02

Published: 2017.06.01

\begin{abstract}
This article presents the research results of roughness and topography of the surface of Inconel 718 nickel alloy after shot peening. The evaluation of stereometric properties of the surface layer of the examined material was performed based on the amplitude, height and Abbott-Firestone curve parameters. The shot peening was carried out on the impulse shot peening stand. The impact energy $E_{z}$, distance between the traces $x_{s}$ and the ball diameter $\mathrm{d}_{\mathrm{k}}$ were changed in the range: $\mathrm{E}_{\mathrm{z}}=60 \div 240 \mathrm{~mJ}, \mathrm{x}_{\mathrm{s}}=0,15 \div 0,5$ $\mathrm{mm}, \mathrm{d}_{\mathrm{k}}=3,95 \div 12,45 \mathrm{~mm}$. The T8000 RC 120-140 device of the Hommel-Etamic company, along with the software, was used for measuring the surface roughness and for determining the material bearing curve. As a result of the machining, the surface roughness was reduced and the selected functional parameters were improved.
\end{abstract}

Keywords: surface roughness, shot peening, Inconel 718.

\section{INTRODUCTION}

The Inconel nickel alloys are classified as advanced materials, which are successfully used in the aerospace, chemical and energy industries [2]. They have good mechanical and plastic properties. Due to the low efficiency of thermal conductivity and good corrosion resistance, nickel alloys are used for such machine components as turbines, discs, shafts, compressor blades, exhausts and combustion chambers. The share of nickel alloys, as a construction material, in the aerospace industry, ranges from $22 \%$ to $34 \%[2,8]$. The disadvantage of nickel alloys is their low wear resistance due to friction, which can be eliminated by using surface machining [18].

Burnishing is one of the varieties of the surface machining, which enables the improvement of stereometric and physical properties of the top layer. During burnishing, the phenomenon of local plastic deformation of the surface layer is used at the ambient or elevated temperature, caused by the impact of the hard tool on the surface [16].
Burnishing makes it possible to reduce the surface roughness and to increase the material bearing $[12,24]$. The cyclical impact of the hard tool on the processed surface causes the formation of micro-grooves, which can be the potential "reservoirs" of the lubricant, and thus contribute to the increased resistance of these surfaces to wear and tear [9]. The change in the concentration of the crystalline structure defects is also the effect of burnishing machining, resulting in compressive stresses constituted in the surface layer [25]. Changing the state of residual stresses results in an increase in fatigue durability $[11,23]$. Burnishing is successfully used not only to improve the properties of the surface layer, but it is also used to round the edges of the workpiece [15]. Physical properties of the surface layer shaped during the machining and the geometric structure of the surface affect the energy state and adhesion properties of the surface $[13,17]$.

In literature, we can find a lot of work devoted to shot peening of titanium and aluminium alloys [25] as well as steel $[4,11]$. Few publications are 
about shot peening nickel alloys $[1,14,21]$. Ultrasound shot peening (USP) rebuilds the geometry structure of nickel alloys. Machining traces are "punched" on the surface, which depth and amount on the surface depends on the material, of which the balls are made, the processing time and the impact energy [19]. The use of too much pressure during the machining of Inconel 718 nickel alloy results in an increase in surface roughness, which is due to the insufficient ability to absorb the deformation by the machined surface [14,21].

During the finishing treatment of nickel alloys, the physical properties of the surface layer are changed. As a result of the conducted shot peening of the Inconel 718 alloy, compressive stresses are deposited on the surface layer [19, 20], which translates into the increased fatigue strength $[1,3]$. The stress depth and its value depends on the machining time, material of the balls and the distance at which the workpiece is located from the nozzle [19].

Stress measurements are most often done with X-ray techniques, however the [5, 6] works have successfully used the eddy currents in order to determine the state of stresses after shot peening the samples from the Inconel 718 alloy. This method involves measuring the frequency of the eddy current in order to obtain the electrical conductance signal near the surface, which can be transformed into a stress profile.

Not only are the machine components subjected to shot peening machining, but it is also

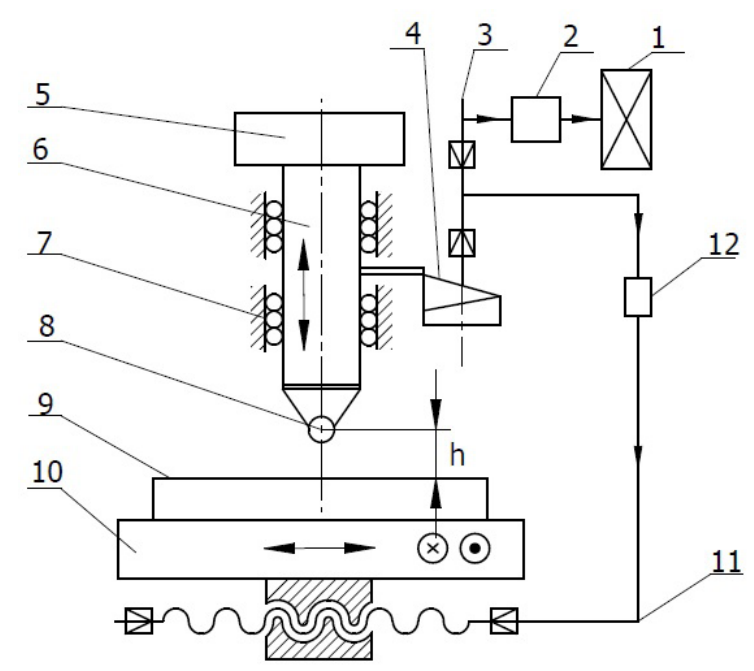

Fig. 1. Schema of a stand for impulse shot peening: 1 - engine, 2 - gear, 3 - shaft, 4 - cam, 5 - weight, 6 - beater, 7 - ball guides, 8 - ball, 9 - workpiece, 10 - table, 11 - guide screw, 12 - gear successfully used for processing stents made of inter-metallic "Nitional" (NiTi) alloy, in order to improve the wear resistance [7].

Based on the conducted literature review, it can be stated that there are a lot of works on the burnishing machining of nickel alloys. However, these studies are primarily concerned with the physical properties of the surface layer and the performance characteristics of machine elements. However, there are not many works that would describe the stereometric properties of nickel alloys after shot peening. It is therefore reasonable to undertake studies to determine the impact of technological parameters of shot peening on the geometric structure of the surface of nickel alloy elements. The evaluation was performed based on amplitude, height and Abbott-Firestone curve parameters, which provide information on the state of co-operating elements.

\section{RESEARCH METHODOLOGY}

The research used the nickel alloy samples of the HRSA (Heat Resistant Super Alloys) group, that is Inconel 718. Table 1 shows the chemical composition and the selected properties of nickel alloy used in the experiment.

The impulse shot peening was made on a shot peening stand, which is presented in Figure 1. During machining, the work surface of the workpiece (9) was subjected to the hits of the beater (6) of a known mass, which can be changed by replacing the weight (5), raised to the height $h$ by the cam (4). The beater with a ball (8), which is an interchangeable element, moves while operating in the ball guides (7). The table, on which the workpiece is attached, performs a feed movement, and the speed of this movement may be controlled with a guide screw (11) and the gear (12).

Shot peening was realized for the following technological parameters:

- impact energy: $\mathrm{E}_{\mathrm{z}}=60 \div 240 \mathrm{~mJ}$,

- distance between traces: $\mathrm{x}_{\mathrm{s}}=0.15 \div 0.5 \mathrm{~mm}$,

- ball diameter: $\mathrm{d}_{\mathrm{k}}=3.95 \div 12.45 \mathrm{~mm}$.

Milling preceded the shot peening machining, which was done using a hexagonal milling head with an external diameter $D=40 \mathrm{~mm}$, equipped with circular plates of sintered carbides covered with the TiAl coating. The following technological parameters were used for processing: $a_{p}=0.5$ $\mathrm{mm}, v_{c}=40 \mathrm{~m} / \mathrm{min}, f_{z}=0.08 \mathrm{~mm} /$ tooth. Exten- 
Table 1. The chemical composition and selected properties of nickel alloy Inconel 718 [8]

\begin{tabular}{|c|c|c|c|c|c|c|}
\hline \multicolumn{7}{|c|}{ Chemical composition [\%] } \\
\hline Mo & $\mathrm{Ti}$ & $\mathrm{C}$ & \multicolumn{2}{|c|}{$\mathrm{Si}$} & $\mathrm{Cr}$ & $\mathrm{Fe}$ \\
\hline $2.8-3,3$ & $0.65-$ & 0.08 & \multicolumn{2}{|c|}{0.35} & $17-21$ & $11,16-22.5$ \\
\hline Co & $\mathrm{Nb}(+\mathrm{Ta})$ & $\mathrm{Al}$ & $\mathrm{Mn}$ & B & $\mathrm{Cu}$ & $\mathrm{Ni}$ \\
\hline 1 & $4.75-5.5$ & $0.2-0.8$ & 0.35 & 0.006 & 0.3 & rest \\
\hline \multicolumn{4}{|c|}{ Tensile strength [MPa] } & \multicolumn{3}{|c|}{1400} \\
\hline \multicolumn{4}{|c|}{ Yield point [MPa] } & \multicolumn{3}{|c|}{864} \\
\hline \multicolumn{4}{|c|}{ Elastic modulus [GPa] } & \multicolumn{3}{|c|}{205} \\
\hline \multicolumn{4}{|c|}{ Hardness [HB] } & \multicolumn{3}{|c|}{$350-450$} \\
\hline
\end{tabular}

sive cooling was applied while milling with the cooling-lubricating liquid - Mobile Cut.

Measurements of surface roughness and 3D topography were made using the T8000RC 120 140 device of the Homel Etamic company, which allows to determine amplitude, horizontal, mixed, height and Abbott-Firestone curve parameters.

\section{RESEARCH RESULTS}

The implementation of the research allows us to present the effect of shot peening parameters on the amplitude parameters of roughness $\mathrm{Ra}$ (arithmetic mean of the profile ordinates), and height $\mathrm{Rz}$ (the highest profile height), Rp (the height of the biggest profile elevation) and $\mathrm{Rv}$ (the depth of the lowest profile cavity), as well as the parameters of the material bearing curve Rpk (the reduced height of the elevation), Rk (the depth of the roughness core), Rvk (the reduced depth of the cavity). The selection of the above parameters was an indication of the possibility of evaluating the stereometric features of the surface layer in the functional aspect. The roughness parameters
$\mathrm{Rv}, \mathrm{Rp}$, and the material share curve allow us to predict how the given surface will behave in cooperation with another surface $[10,22]$.

The surface roughness before shot peening (after milling) was within the range of $\mathrm{Ra}=(0.65$ $\div 0.69) \mu \mathrm{m}, \mathrm{Rz}=(3.1 \div 3.28) \mu \mathrm{m}, \mathrm{Rp}=(1.68 \div$ 2.02) $\mu \mathrm{m}, \mathrm{Rv}=(1.24 \div 1.27) \mu \mathrm{m}, \mathrm{Rpk}=(0.79 \div$ $0.96) \mu \mathrm{m}, \mathrm{Rk}=(1.56 \div 1.96) \mu \mathrm{m}, \mathrm{Rvk}=(0.19 \div$ 0.39) $\mu \mathrm{m}$.

The topography of the surface formed by the preceding machining is characterised by an even distribution of micro-unevenness, with a clearly defined vertices and depressions. The one-way structure is formed (Fig. 2a).

As a result of the shot peening machining, the topography surface is reconfigured (Fig. 2b). A surface with numerous cavities is formed, which is the result of the ball hitting the machined surface. The Ssk parameter is decreased, so it can be assumed that the material concentrates near the apex of the profile, and thus the surface can be considered as a good bearing surface [22].

Figures for Fig. 3 to Fig. 5 present the influence of the impact energy on the analysed roughness parameters of the surface. The increase in

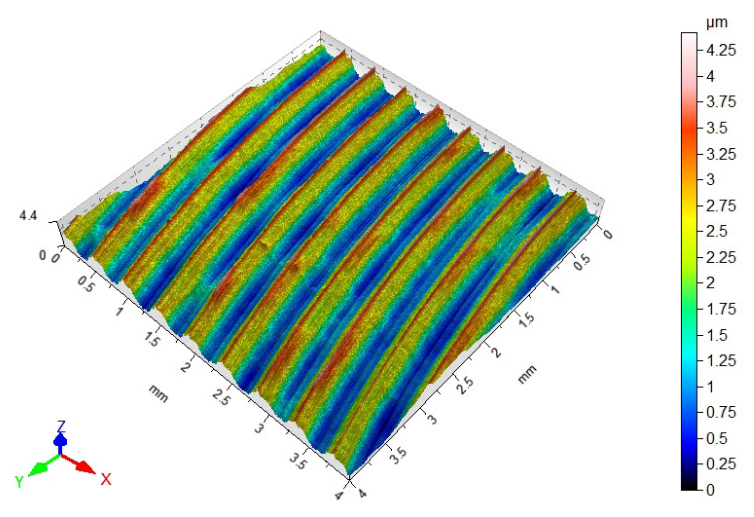

$\mathrm{Sa}=0.778 \mu \mathrm{m}, \mathrm{Sz}=4.42 \mu \mathrm{m}, \mathrm{Ssk}=0.179$

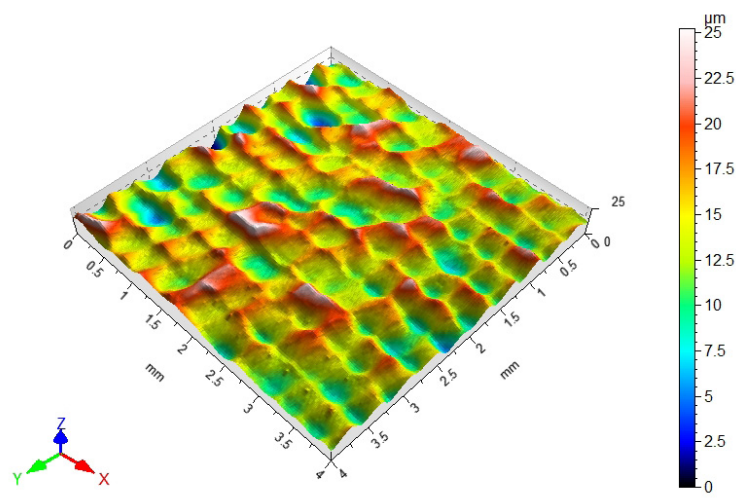

$\mathrm{Sa}=2.26 \mu \mathrm{m}, \mathrm{Sz}=25.4 \mu \mathrm{m}, \mathrm{Ssk}=0.035$

Fig. 2. Topoghrapy of the Inconel 718 alloy surface after: milling (left), shot peening (right) $\left(\mathrm{E}_{\mathrm{z}}=180 \mathrm{~mJ}, \mathrm{x}_{\mathrm{s}}=0.3 \mathrm{~mm}, \mathrm{~d}_{\mathrm{k}}=3.95 \mathrm{~mm}\right)$ 


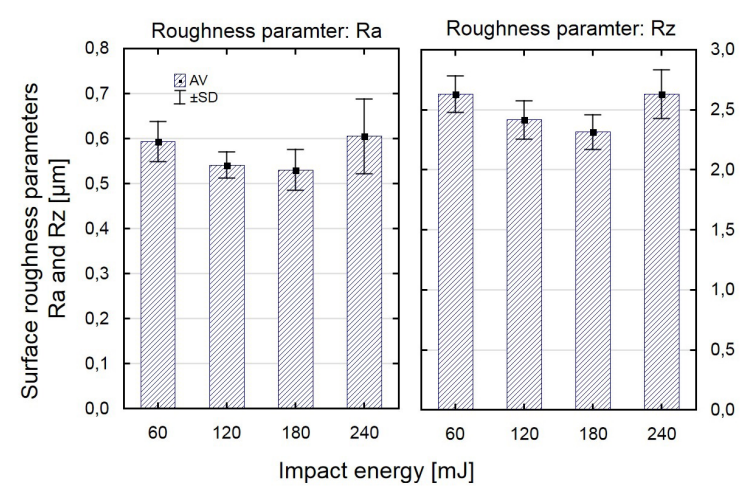

Fig. 3. Effect of impact energy on the surface roughness parameters $\mathrm{Ra}$ and $\mathrm{Rz}\left(\mathrm{x}_{\mathrm{s}}=0.3 \mathrm{~mm}, \mathrm{~d}_{\mathrm{k}}=6 \mathrm{~mm}\right)$

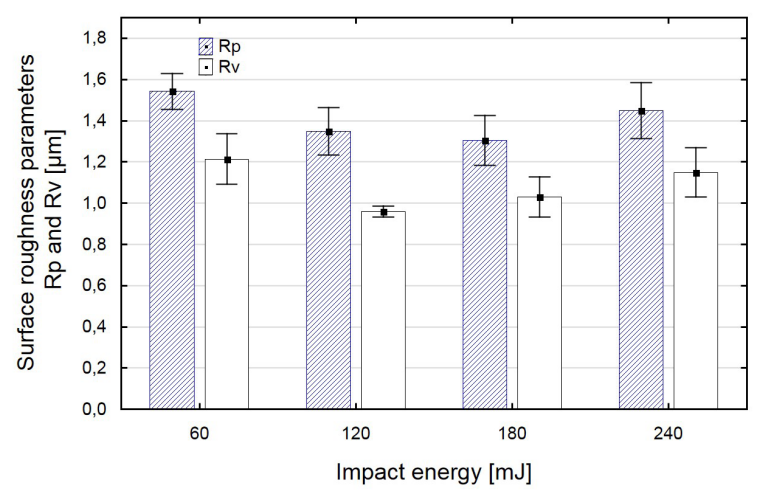

Fig. 4. Effect of impact energy on the surface roughness parameters $\operatorname{Rp}$ and $\operatorname{Rv}\left(\mathrm{x}_{\mathrm{s}}=0.3 \mathrm{~mm}, \mathrm{~d}_{\mathrm{k}}=6 \mathrm{~mm}\right)$

collision energy results in a decrease of surface roughness to the minimum value achieved for $\mathrm{E}_{\mathrm{z}}=120 \div 180 \mathrm{~mJ}$, followed by an increase in the roughness parameters. Applying the impact energy greater than $180 \mathrm{~mJ}$ results in larger "holes" made in the machined surface, resulting in deterioration of the surface quality. The Ra parameter in relation to the value after milling has decreased from $9.6 \%$ to $20.8 \%$, while the Rz parameter from $17.5 \%$ to $27.4 \%$, depending on the impact energy.

Increasing the collision energy causes intense deformation of micro-unevenness after pretreatment. Their vertices are cut, which translates into the value decrease of the $\mathrm{Rp}$ parameter from $16.6 \%$ to $29.4 \%$ (Fig. 4), and the Rpk parameter from $4.7 \%$ to $11 \%$ (Fig. 5 ) with respect to the value after milling. This allows us to infer the probable increase in wear resistant of the processed element after shot peening.

The cyclical impact of the ball, with the specified energy, on the work surface, causes the formation of cavities, which contributes to the increase in the Rvk parameter, and thus the increase in the lubricant retention capacity (Fig. 5).

The increase in the distance between the machining traces results in a reduction in the degree of coverage, and thus the non-uniform deformation of the work surface. The improvement of the roughness parameters $\mathrm{Ra}, \mathrm{Rz}$ (Fig. 6) and $\mathrm{Rp}, \mathrm{Rv}$ (Fig. 7) in relation to the value after milling takes place in the range $\mathrm{x}_{\mathrm{s}}=0.15 \div 0.4 \mathrm{~mm}$.

The effect of the distance between traces on the Abbott-Firestone curve parameters (Fig. 8) is similar to the $\mathrm{Ra}, \mathrm{Rz}, \mathrm{Rp}$ and $\mathrm{Rv}$ parameters. The increase in the distance between machining traces translates into a smaller share of elastic and plastic deformations, which results in the increase of the Rpk, Rk, Rvk parameters. The improved wear resistant, expressed by the Rpk parameter, occurs during machining with $\mathrm{x}_{\mathrm{s}}=0.15 \div 0.4 \mathrm{~mm}$ (Fig. 8). The depth of the roughness core Rk during machining with $\mathrm{x}_{\mathrm{s}}=0.15 \mathrm{~mm}$ decreases with

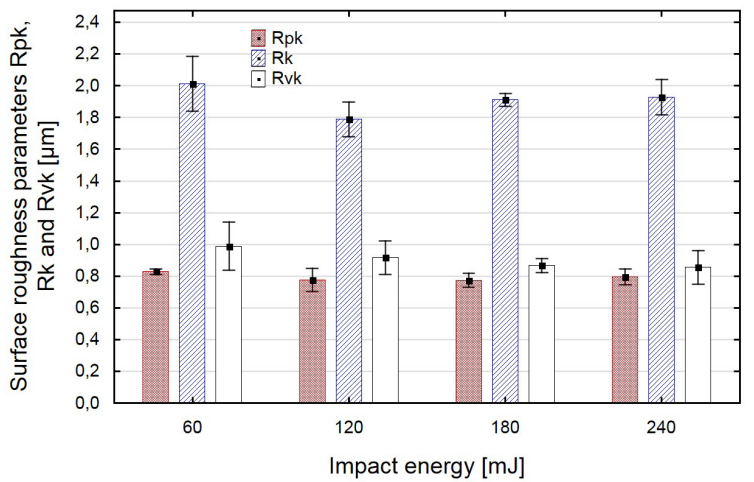

Fig. 5. Effect of impact energy on the surface roughness parameters Rpk, Rk and Rvk $\left(\mathrm{x}_{\mathrm{s}}=0.3 \mathrm{~mm}, \mathrm{~d}_{\mathrm{k}}=6 \mathrm{~mm}\right)$

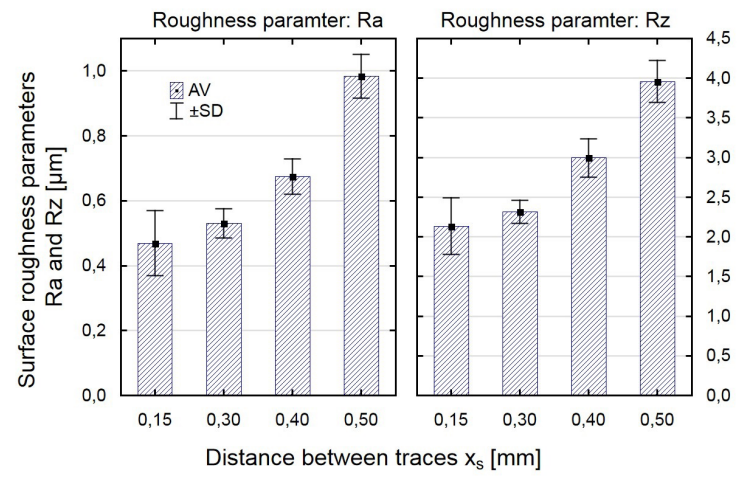

Fig. 6. Effect of distance between traces on the surface roughness parameters $\mathrm{Ra}$ and $\mathrm{Rz}$ $\left(\mathrm{E}_{\mathrm{z}}=180 \mathrm{~mJ}, \mathrm{~d}_{\mathrm{k}}=6 \mathrm{~mm}\right)$ 


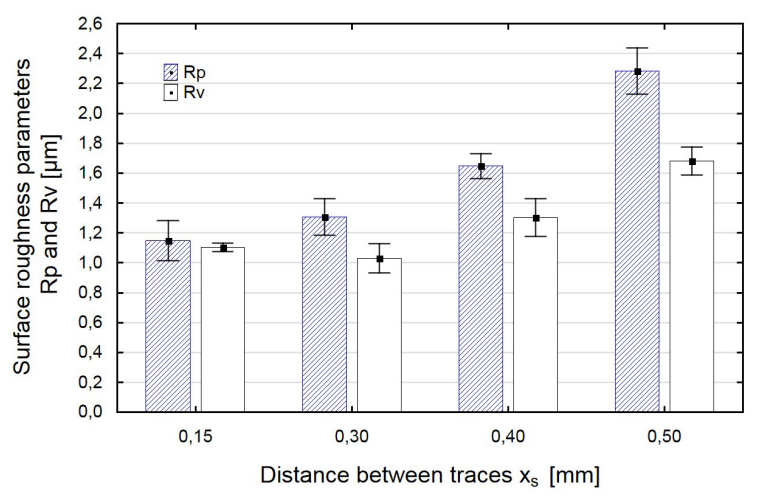

Fig. 7. Effect of distance between traces on the surface roughness parameters $\mathrm{Rp}$ and $\mathrm{RV}$ $\left(\mathrm{E}_{\mathrm{z}}=180 \mathrm{~mJ}, \mathrm{~d}_{\mathrm{k}}=6 \mathrm{~mm}\right)$

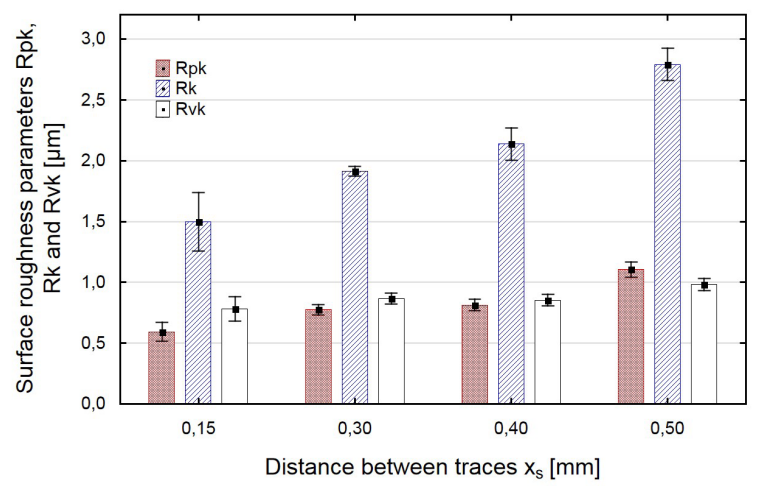

Fig. 8. Effect of distance between traces on the surface roughness parameters Rpk, Rk and Rvk $\left(\mathrm{E}_{\mathrm{z}}=180 \mathrm{~mJ}, \mathrm{~d}_{\mathrm{k}}=6 \mathrm{~mm}\right)$

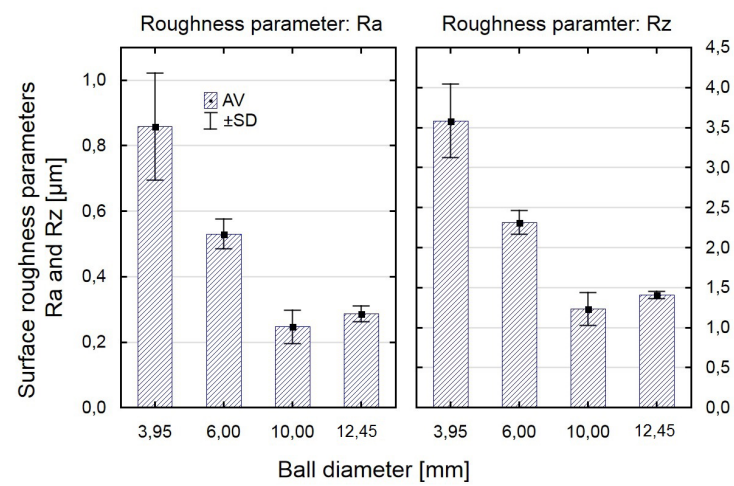

Fig. 9. Effect of ball diameter on the surface roughness parameters $\mathrm{Ra}$ and $\mathrm{Rz}$ $\left(\mathrm{E}_{\mathrm{z}}=180 \mathrm{~mJ}, \mathrm{x}_{\mathrm{s}}=0.3 \mathrm{~mm}\right)$

respect to the value after milling. This means that the "surface load" is improved by $15 \%$, that is, after a period of reaching a significant part of the surface it will contact the surface of the co-operating element. The Rvk parameter, responsible for maintaining the lubricant, increased from 2.7 to 3 times in relation to the value after the pretreatment.

Figures for Fig. 9 to Fig. 11 present the effect of the ball diameter on the roughness parameters. The decrease in surface roughness parameters with the increase in the diameter of the burnishing element may be be explained by the decreasing depth of the impression along with the decrease of the burnishing element curvature.

During the ball processing with $\mathrm{d}_{\mathrm{k}}=3.95 \mathrm{~mm}$, the burnishing element creates a smaller contact surface with the workpiece, resulting in more intense plastic and elastic deformations, which results in the increase in of the roughness parameters: Ra, Rz, Rp and Rv (Fig. 9 and Fig. 10).

For the ball diameter in the range of $d_{k}=6 \div$ $12.45 \mathrm{~mm}$ there is an improvement of functional parameters $\mathrm{Rpk}$ and $\mathrm{Rk}$ in relation to the surface after pre-treatment (Fig. 11). The Rpk parameter

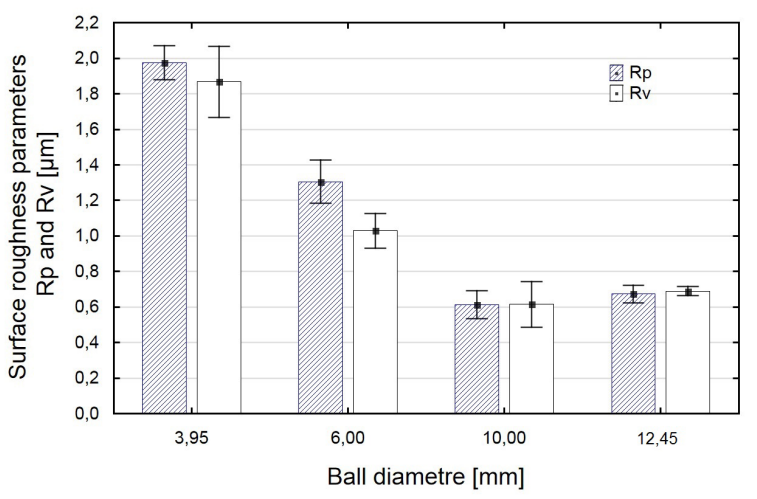

Fig. 10. Effect of ball diameter on the surface roughness parameters $\mathrm{Rp}$ and $\mathrm{Rv}$ $\left(\mathrm{E}_{\mathrm{z}}=180 \mathrm{~mJ}, \mathrm{x}_{\mathrm{s}}=0,3 \mathrm{~mm}\right)$

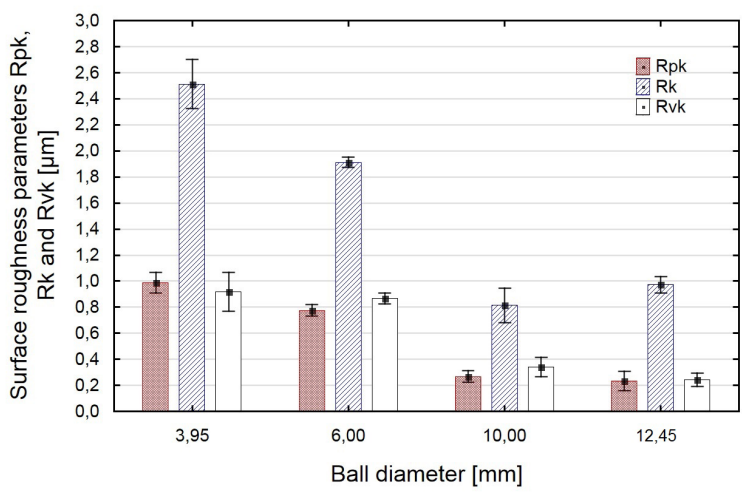

Fig. 11. Effect of ball diameter on the surface roughness parameters Rpk, Rk and Rvk $\left(\mathrm{E}_{\mathrm{z}}=180 \mathrm{~mJ}, \mathrm{x}_{\mathrm{s}}=0.3 \mathrm{~mm}\right)$ 

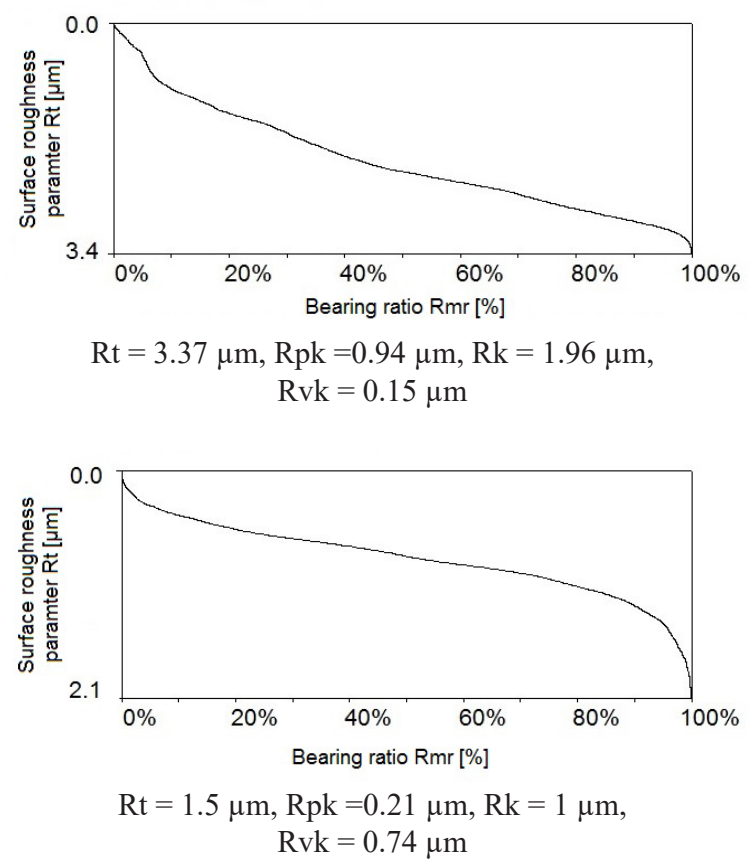

Fig. 12. Abbott - Firestone'a curve after: milling (above), shot peeing $\left(\mathrm{E}_{\mathrm{z}}=180 \mathrm{~mJ}, \mathrm{x}_{\mathrm{s}}=0.15 \mathrm{~mm}\right.$, $\left.\mathrm{d}_{\mathrm{k}}=6 \mathrm{~mm}\right)$

is decreased from 1.13 to 3.77 times, while the $\mathrm{Rk}$ parameter from 1 to 2.17 times in relation to the value after milling.

The shape of the Abbott-Firestone curve contains information about the condition of the surface in terms of its usefulness (Fig. 12). After milling, the curve of the material bearing should be classified as a degressive curve. It is characterised by a large angle of incline. The surface described by this curve variant is characterised by "sharp" vertices of micro-unevenness and a small bearing of material. After shot peening, the Abbott-Firestone curve is slightly inclined, which may indicate a high wear resistant. It is a degenerative-progressive curve [22].

\section{CONCLUSION}

The study analysed the impact of technological parameters of shot peening on the geometric structure of the surface of Inconel 718 nickel alloy after milling. The following conclusions summarise the results of the conducted research:

- shot peening the INCONEL 718 nickel alloy causes the geometric restructuring of the surface after pre-treatment,

- improvement of amplitude and height parameters with respect to values after milling occurs during processing with the following parameters: $\mathrm{E}_{\mathrm{z}}=60 \div 240 \mathrm{~mJ}, \mathrm{x}_{\mathrm{s}}=0.15 \div 0.4 \mathrm{~mm}$ and $\mathrm{d}_{\mathrm{k}}=6 \div 12.45 \mathrm{~mm}$,

- shot peening reduces the Rp parameter from $11 \%$ to $66.8 \%$ and Rpk from $4.7 \%$ to $73.4 \%$ with respect to the value after milling,

- shot peening of the INCONEL 718 alloy results in the improvement of the lubricant retention capability,

- the material bearing curve before shot peening is a regressive curve, after the machining it becomes degressive-progressive.

\section{REFERENCES}

1. Afazov S. M., Becker A. A., Hyde T. H.: Effects of micro-stresses from machining and shot-peening processes on fatigue life. International Journal of Advanced Manufacturing Technology, 51, 2010, 711-722.

2. Arunachalam R.M., Mannan M.A., Spowage A.C: Surface Integrity when Machining Age Hardened Inconel 718 with Coated Carbide Cutting Tools. International Journal of Machine Tools \& Manufacture, 44, 2004, 1481-1491.

3. Bhowal P., Stolz D., Wusatowska - Sarnek A., Montero R.: Surface effects on low cycle fatigue behavior in INCONEL 718 alloy. [W]: Superalloys, 2008, 417-423.

4. Bucior M., Galda L., Stachowicz F., Zielecki W.: The effect of technological parameters of shot peening on the surface roughness of 51CrV4 steel. [W]: Advances in Mechanics: Theoretical, Computational and Interdisciplinary Issues, 2016, 105-108 .

5. Chandrasekar R., C.H. Lo C., Frishman A., Larson B., Nakagawa N: Quantification of precipitates and their effects on the response of nickel-base superalloy to shot peening. [W]: AIP Conferences Proceedings, 2012, 1430-1437.

6. Chandrasekar R., Frishman A., Larson B., C.H. Lo C., Nakagawa N: Effects of Microstructure on Eddy Current Residual Stress Characterization of Shot-Peened Inconel 718. The Journal of The Minerals, Metals \& Materials Society (TMS), Vol. 64, 2, 2012, 257-264.

7. Dimakos K., Mariotto A., Giacosa F.: Optimization Of The Fatigue Resistance Of Nitinol Stents Through Shot Peening. Procedia Engineering, 2, 2016, 1522-1529.

8. Dul I: Zastosowanie i przetwarzanie stopów niklu w przemyśle lotniczym. Przegląd Spawalnictwa, 81, 7-8, 2009, 67-73.

9. Galda L., Sep J., Prucanl S.: The effect of dimples geometry in the sliding surface on the tribological 
properties under starved lubrication conditions. Tribology International, 99, 2016, 77-84.

10. Grzesik W.: Wpływ topografii powierzchni na właściwości eksploatacyjne części maszyn. Mechanik, 8-9, 2015, 587-593.

11. Kubit A., Bucior M., Zielecki W., Stachowicz F.: The impact of heat treatment and shot peening on the fatigue strength of $51 \mathrm{CrV} 4$ steel. Procedia Structural Integrity, 2, 2016, 3330-3336.

12. Kułakowska A., Patyk R., Bohdal Ł., Kałduński P., Chodór J.: Wybrane aspekty ekoinnowacyjnej obróbki nagniataniem. Annual Set The Environment Protection Rocznik Ochrona Środowiska, 18, 2016, 478-492.

13. Kwiatkowski M. P., Klonica M., Kuczmaszewski J., Satoh S.: Comparative Analysis of Energetic Properties of Ti6Al4V Titanium and EN-AW2017A (PA6) Aluminum Alloy Surface Layers for an Adhesive Bonding Application. Ozone Science \& Engineering, Vol. 35, 3, 2013, 220-228.

14. López de Lacalle L. N., Lamikiz A., Sánchez J. A.: The effect of ball burnishing on heat-treated steel and Inconel 718 milled surfaces. International Journal of Advanced Manufacturing Technology, 32, 2007, 958-568.

15. Matuszak J., Zaleski K: Edge states after wire burnishing of magnesium alloys. Aircraft Engineering and Aerospace Technology, Vol. 86, 4, 2014, 328-335.

16. Przybylski W.: Technologia obróbki nagniataniem. Wydawnictwo Naukowo-Techniczne, Warszawa, 1987.

17. Rudawska A., Reszka M., Warda M., Miturska I., Szabelski J., Stancekova D., Skoczylas A.: Milling as a method of surface pre-treatment of steel for adhesive bonding. Journal of Adhesion Science and Technology, Vol. 30, 23, 2016, 2619-2636.

18. Rudnicki J., Borowski T., Garbacz H., Wierzchoń T.: Kształtowanie właściwości mechanicznych stopu niklu Inconel $625 \mathrm{w}$ procesie azotowania jarzeniowego. Tribologia, 3, 2009, 209-218.

19. Sandá A., García Navas V, Gonzalo O.: Surface state of Inconel 718 ultrasonic shot peened: Effect of processing time, material and quantity of shot balls and distance from radiating surface to sample. Materials and Design, 32, 2011, 2213-2220.

20. Sanz C., Garcia Navas V., Gonzalo O., Vansteenkiste G.: Study of surface integrity of rapid manufacturing parts after different thermal and finishing treatments. Procedia Engineering, 19, 2011, 294-299.

21. Sequera A., Fu C. H., Guo Y. B, Wei X. T.: Surface Integrity of Inconel 718 by Ball Burnishing. Journal of Materials Engineering and Performance, 23, 2014, 3347-3353.

22. Wieczorowski M., Cellary A., Chajda J.: Przewodnik po pomiarach nierówności powierzchni czyli o chropowatości i nie tylko. Zakład Poligraficzno - Wydawniczy M - Druk, Poznań, 2003.

23. Zaleski K.: The effect of vibratory and rotational shot peening and wear on fatigue life of steel. Eksploatacja i Niezawodnosc Maintenance and Reliability, Vol. 19, 1, 2017, 102-107.

24. Zaleski K., Skoczylas A.: Effect of vibration shot peening parameters upon shapes of bearing curves of alloy steel surface. Advances in Science and Technology Research Journal, Vol. 9, 25, 2015, 20-26.

25. Zaleski R., Zaleski K., Gorgol M., Wiertel M.: Positron annihilation study of aluminum, titanium, and iron alloys surface after shot peening. Applied Physics A-Materials Science \& Processing, No. 2, Vol. 120, 2015, 551-559. 